\title{
Shaming Fathers into Providers: Child Support and Fatherhood in the South African Media
}

\author{
Polite Chauke ${ }^{1}$ and Grace Khunou ${ }^{*}, 2$ \\ ${ }^{1}$ Commission for Gender Equality (CGE), Johannesburg, South Africa \\ ${ }^{2}$ Sociology Department, University of Johannesburg, Kingsway Campus, Auckland Park Johannesburg, 2000, South \\ Africa
}

\begin{abstract}
The media influence society's understanding of gender and other social phenomena including how we view fatherhood. Fatherhood is rarely presented positively in both visual and print media. Through an analysis of newspaper articles from The Sowetan, City Press, The Daily Sun and The Pretoria News, this article shows how shaming is used to represent fatherhood and child support in the South African print media. These representations, the article argues are limiting and provide fewer positives for fathers and fail to account for socio-economic challenges experienced in relation to fatherhood. In conclusion, the article illustrates that the media could play an important role in presenting a balanced sense of fatherhood, where affirmation of positive fatherhood is used as a more effective way of representing fatherhood in the media.
\end{abstract}

Keywords: Child support, fatherhood, gender, masculinities, news papers, shaming.

\section{INTRODUCTION}

Father absence is a serious challenge in South Africa. According to the SAIRR [1] in 2009 there were approximately $52 \%$ of African children with absent fathers as compared to $41 \%$ amongst Coloured people, $12 \%$ amongst Indians and 15\% amongst Whites. Although the number of absent fathers is high for African children, beyond the statistics and headlines there are unheard tales of presence and positive fatherhood in South Africa [2]. One of the reasons for such high rates of father absence among the African population is linked to apartheid engineering and the migrant labour system [3, 4]. Consequently, the African family was disrupted and thus reconceptualised. Studies on early African cultures show that dominant conceptualisations of fatherhood that focused on involved father responsibilities like; protection, moral authority, family responsibilities, provision and the function of being a role model especially for young men was signified [5, 6]. However, as a result of colonialism, apartheid and the migrant labour system these conceptions and notions of a healthy functioning African family have been negatively affected. Most black men's roles as providers and caregivers have been neglected, whereas those of white men have been signified through the provision of sustainable and permanent employment in urban cities $[3,4,7]$. It is therefore important to acknowledge that fatherhood is a complex social practice that is context specific $[8,9]$.

This context specificity is important in efforts to reposition father's roles in their children's lives; nevertheless

\footnotetext{
*Address correspondence to this author at the Sociology Department, University of Johannesburg, Kingsway and University Rds, Auckland Park, South Africa; Tel: 011559 3346; E-mail: Gracek@uj.ac.za
}

most media representations miss this important lens. The media's take on fatherhood is important as it plays a vital role in influencing what is important and worth thinking about [10]. Furthermore its role is significant in maintaining and challenging social orders and categories along the lines of gender, class and race, thus providing the media with power to reflect and create multiple truths and realities [11]. However, these multiple truths often reflect ideals that are gender biased. Given the media's propensity towards gendered representations it has been found that the media also facilitates understanding of fatherhood from the notions of hegemonic masculine traits that signify men as only providers $[2,8,12]$. Again given the idea that all fathers are able and willing providers [13] there is therefore an assumption made by policymakers and the media, which suggests that fathers who fail to support their children simply refuse to do so [14]. This is so even when studies of maintenance in Southern Africa conclude that men are not opposed to the obligation to maintain their children $[15,16]$.

Although the media's power to influence does not necessary influence the intensity and direction of attitudes, it notwithstanding sets the agenda with regards to what is important [17]. Therefore, negative constructions of fatherhood in media messages are detrimental to positive ideas of fatherhood. Research illustrates that the media such as radio, television and newspapers are society's most common source of information, yet there are rare representations of positive fatherhood [18]. Negative media presentations of fathers seldom acknowledge structural effects such as the lack of resources, insufficient work opportunities combined with low incomes and inadequate social policies and social intervention [2, 19, 20]. These structural forces contribute to some of the reasons most South African fathers are not involved in their children's 
live. Research also argues that the media rarely represents fathers as intimate, nurturing parents, which is part of fatherhood [18].

Like the media, the Maintenance system also downplays the emotional and psychosocial role played by fathers. The challenges experienced and multiple roles played by fathers are also rarely acknowledged [12, 16, 20]. Again the law only requires fathers to illustrate their role in provider terms since it mostly focuses on their payment and or non-payment of maintenance, but fails to signify their presence and contribution in other ways $[10,21]$. The flaw in legitimising fatherhood only through signifying the provider role is that it marginalises men that are socioeconomically unable to provide. When a father is unable to financially provide for their children, his parenting status and powers are relinquished. It needs to be noted that this happens in a context where many women are unable to access maintenance as some men refuse and or default from paying child support even when they can afford to maintain $[12,16]$. In South Africa, the media and public discourse on child support and fatherhood tends to indiscriminately shame and criminalise fathers that face challenges with financial provision for their children. This article therefore aims to show how shaming is used as a tool to correct and realign fathers to the notion of man as primarily a provider.

Shaming is usually misconstrued as a tool to correct, to set straight, however, its effects are not always positive. Shame is, "a painful emotion caused by consciousness of guilt, shortcoming, or impropriety" [22]. Therefore, it is a process that evokes feelings of humiliation, dishonour and disgrace. The definition of shame as an experience of a selfconscious emotion requiring cognition of self and the ability to evaluate one's behaviour against a standard and the recognition of one's failure is significant for our purposes in this article. The emphasis of 'standard' and 'failure' in this definition highlights that the assumed standard for what it means to be a father is mainly to fulfil the provider role, consequently the failure to do so suggests that one has failed to be a man. In studies of masculinities, it is shown that shaming is used as "an attempt to shut down the presence of ambiguities in gender" [23]. In this sense to be a father, one must be a provider, nothing in between is accepted. This is a challenge for men who are unable to provide and are unable to bear the shame that comes with being unable to provide $[4,24,25]$. This article therefore contributes to debates on father connections by showing how shaming is used in negative media representation of maintenance defaulting fathers as a way to realign manhood to hegemonic notions of masculinity.

The provider role played by fathers in families is significant, especially given the continued wage gains associated with being a man as compared to being a woman. However, there are factors that hinder many fathers from effectively performing this specific role. According to the Labour Force Survey, unemployment for men stood at $23.4 \%$ in 2013 [26]. For African men unemployment stood at $15 \%$ as compared to $3.9 \%$ for white men [26], these statistics reflect that there are challenges that especially African men in South Africa are facing with regards to the fulfilment of the provider role. Given these statistics and other socio-economic challenges linked with the provider role and conceptions of masculinities, men should be seen as more than just the provider [12]. Again, for enhancement of societal wellbeing, the media needs to acknowledge different conception of fatherhood through a presentation of balanced stories of fatherhood and through a focus of positive notions of fatherhood.

\section{METHOD}

This article is drawn from a broader qualitative study on fatherhood and the South African maintenance system. The arguments made in this article are however based on an analysis of 6 newspaper articles derived from, the Sowetan, City Press, The Daily Sun and Pretoria News. The Sowetan newspaper is a daily tabloid newspaper, that targets a black African audience and had a readership of 1,618,000 in 2011. The article examined from the Sowetan looks at the state of fatherlessness in South Africa titled $S A$ : A nation of deadbeat dads [27]. The article analysed from City Press is based on the story of former Hawks spokesman and author McIntosh Polela and is titled; on-air spat over papgeld [28]. The article focuses on challenges Polela had with paying maintenance.

On the other hand, the City Press newspaper is a Sunday newspaper that targets the middle-class and had a readership of 1, 604, 000 in 2011. The City Press articles provide a reflection that fathers want to be more than just financial providers to their children and the title is Fathers are more than just ATMs [28], is an interesting article as it began to reposition how the media presents fathers through showing what it means to be a father in broader terms. However, the other article from the City Press [29] speaks to soccer star Teko Modise's default on maintenance, the article is titled: Super-Sport United Captain a deadbeat Dad, Court Rules.

The Daily Sun is a daily tabloid which targets the African working class audience. It is the biggest newspaper in South Africa and in 2011, it had a readership of 5,220,000, the title of the article reviewed is, "Papgeld dodgers cornered! Offenders could be nabbed even if stopped at roadblock" [30], this article captures how fathers that owe maintenance will possibly face jail for defaulting on payment. Finally, an examination of the article from the Pretoria newspaper titled; Teko jail threat over defaulting [31] is also undertaken. The Pretoria News is a daily newspaper which also targets the middle-class with a readership of 1,08,000. The above article focuses on how soccer star Teko Modise, was threatened with jail for defaulting on maintenance.

All the newspaper articles were chosen on the basis of their relevance to child support and fatherhood and were published in the years 2012 and 2013. The process of selecting the articles was informed by the headlines of the articles that focused on fatherhood and the maintenance system, however, most of these articles focused on especially celebrity fathers who were reported to be defaulting on child maintenance. These newspapers were purposively selected due to the content of the headlines that were relevant to the interest of the study. The selection method that was used to choose the newspaper articles was convenience sampling. Convenience sampling refers to obtaining the unit of analysis in a manner that is convenient. Convenience sampling is a non-probability sampling method that is used to compliment 
the non-representative and non-generalist nature of the qualitative approach [32].

Analysing contents of documents like newspapers requires qualitative procedures for assessing the significance of particular ideas or meanings in the document [33]. As a result, content analysis was used to examine the articles used in this examination, since it is the most flexible, creative and reliable for analysis of print media [17, 34, 35]. Content analysis is therefore, used in a way where textual interpretation is decentred to reconstruct text, uncover underlying social and historical process [36]. For this article, content analysis was used to examine how these particular newspaper articles portray fatherhood.

\section{RESULTS AND DISCUSSION}

Three themes were identified from the analysis of the newspaper article. These themes were shaming of celebrity fathers that are embroiled in child support affairs; Criminalisation as Shaming of failure to pay child support. These two themes indicate how the media plays into the idea of shaming as correcting in relation to hegemonic notions of father as provider. The theme; from Shaming to Affirmation as effective representation of fathers in the Media looks at the notion of fathers being more than financial providers and thus signifies fathers through looking at the importance of positive affirmation for caring fathers. These themes speak specifically to how shaming is centred is how newspapers represent fatherhood in relation to maintenance defaulting.

\section{Ridiculing of Celebrity Fathers: Teko Modise and McIntosh Polela}

Shaming has been identified as a deterrent to the development of positive notions of masculinities and fatherhood. It also demonstrated that low-income single fathers who struggle to pay child support are shamed, labelled and criminalised for not being able to financially provide for their children [14]. Although there is lack of literature that focused specifically on celebrity fathers that are failing to pay child support, there are numerous newspapers articles on how local and international super stars such as Basketball legend Dennis Rodman and Soweto Born soccer star Teko Modise allegedly refuse to pay child support. Through these media reports these men are positioned as representatives of men in general and are also subjected to negative publicity and name calling in public discourses on fatherhood and child support. The article titled; "Teko jail threat over defaulting" [31]; is about soccer sensation, Teko Modise who plays for Mamelodi Sundowns and formerly for Bafana Bafana. In the article he is said to be failing to honour a monthly maintenance order of R31,000. The soccer star was alleged to be in a debt of R52,000 after defaulting in February 2012 according to the court order.

Teko Modise's monthly salary was estimated at R150,000 per month and has allegedly made only two payments of R4,000 since February 2012. The article further indicated that;

"The judge had ordered Modise to make monthly maintenance payments of R31,000 towards his wife and their daughter's upkeep" [31].
The court also listed the soccer star's flashy cars which included a BMW X6, BMW M3, and a BMW 1 Series in the court papers in relations to his divorce from his wife. The Pretoria news [31] also reported that:

"Modise allegedly deregistered their daughter
from his medical aid and refused to give her
money. This came after he kicked out mother
and daughter from their luxurious R1.85
million home earlier last year (2011)" [31].

Ntswaki (his estranged wife) is reported to have said that Modise ignored her pleas for financial help, and got "aggressive" whenever she contacted him. For many young men from Soweto Teko Modise represents an ideal of what it means to be a successful man. The article portrays Teko as a flamboyant playboy who abuses his financial power to disadvantage his family. The characteristics of a playboy are affirmed by the theory of hyper masculine behaviour in which he shows aggression, dominance over women and irresponsible financial spending. Hyper masculinity is defined as the "macho personality" [37] as it consists of callous sexual attitudes towards women; the stereotypical belief that violence is being masculine and the enjoyment of dangerous experiences. For the purpose of this article, the meaning of hyper-masculinity is understood as the exhibition of stereotypic gendered displays of power and consequent suppression of signs of vulnerability or lack of emotional health, which can lead to conflict in one's social surrounding especially in family settings [38].

Teko Modise is also reported as having had defaulted on child support maintenance, consequently negatively impacting his daughter [31]. The article highlights the irony in the soccer player's inability to pay monthly maintenance yet his lavish lifestyle is characterised by flashy cars and a multimillion house all of which reflects a lifestyle of a person with money. One can argue that Teko Modise's refusal to pay child support maintenance as argued in the article illustrates how hyper-masculine behaviour causes conflict in family setting as his need for a flashy lifestyle is conflicting with his duty as a father.

Another case of how hyper-masculine behaviour can cause tension in intimate settings is highlighted in the story of former Hawks spokesman and author McIntosh Polela, who was publicly humiliated when one of the mothers of his six children was called during a radio interview on Radio 702 to confront him about not maintaining his two children, the woman's anger was apparently sparked by Polela's tweet about wanting to buy a Jeep whilst he owed child support of two months as reported in the article, "Polela in on-air spat over papgeld" [28]. The article further suggested that Popela's owing maintenance is an ongoing problem, to which he responded: "It's an orgy of voyeurism. I am only human. Sometimes you do fall short in a month" [28]. Polela is an award winning author of My Father, My Monster, a biography of his heart wrenching tale of an abusive childhood, father absence and living with the fact that his father murdered his mother.

The process of claiming maintenance disadvantages many women who have to travel the ins and outs of the court for claims that at times do not materialise [10]. It is therefore important to acknowledge that issues of child support are 
complex, especially if the parents of the child are in conflict. Both the Sowetan [28] and the Pretoria News [31] articles illustrate the perspective of woman who share the frustration of having to navigate the maintenance system to claim child support from fathers. Although the South African maintenance system states that parents are obliged to provide accommodation, food, clothing, medical and academic services as well as other necessities of life for their dependents $[13,19,21]$, this is seldom adhered to. Furthermore, the Act stipulates that a dependent must be provided for in line with the social position, lifestyle and financial resources of both parents [13].

In the case of Teko Modise and McIntosh Polela, we see how both these public figures are ridiculed and shamed for their inability to sufficiently provide for their children even though they have the means to do so. Unlike these celebrity men, research on ordinary fathers who were mostly unemployed and struggled to make ends meet are also labelled in the same way as fathers who are able but not willing to support their children like Modise and Polela above $[4,11]$.

Fathers who are unable to pay maintenance are in most cases denied access to their children $[12,16,20]$, and thus they are unable to be fathers in other ways. Men's roles in their children's lives are reduced to the provider role, even when they wanted to be there in more ways [12]. Consequently, most unemployed and poor men are refused by circumstances and others around them to be more than the provider, therefore, fathers who are unable to be providers' avoid the shame by resorting to being absent $[4,7]$. Given the heterogeneous experiences of fatherhood, it is important for the media to thus play a much broader role than to solely shame, but to educate fathers who default and the general public through providing a balanced sense of factors that influence different men in relation to defaulting with child maintenance.

\section{Attempts to Make the Maintenance System Work: Criminalization as Shaming of Fathers who Default}

The general position on the imprisoning of fathers that default on child support, is a punitive stance on fatherhood. This stance fails to take into account the conditions of unemployment faced by most of the men who have maintenance cases. The Maintenance Act stipulates that the person with the legal duty to pay maintenance failed to do so, a warrant of arrest should be issued against him [21]. However, the arrest clause in the Maintenance Act fails to acknowledge the socio-economic context of fatherhood, and thus assumes an unrealistic link between being a father and the provider role $[12,14,20]$. Therefore, like in shaming, men who are genuinely unable to pay child maintenance are criminalised. Again, men who had experienced arrests as a result of non-payment of maintenance resent the father label and link it to negativity and possible trouble with the law [12].

The general assumption about men that fail to pay maintenance is that they simply refuse to do so. However, the situation is more complex for men who are forced to redefine their manhood and fatherhood status in the face of unemployment. Conversely, policies like the Maintenance Act are based on assumptions of full employment and gendered notions of the family and parenting. In America the same situation is true where child support enforcement agencies have aggressively pursued non-resident parents who do not pay child support. The enforcement agent garnish their wages, intercepting their tax returns, suspends their drivers' licenses, and initiate criminal proceedings and even boot their vehicles to shame them into complying with child support orders [14].

These methods by enforcement agents are not unique to the US, according to the article; "Papgeld dodgers cornered! Offenders could be nabbed even if stopped at roadblock" [30], defaulting fathers will be cornered everywhere they are found, this will also be done through roadblocks. Advocate Mohamed of the Department of Justice and Constitutional Development explained that the department along with the police intend to arrest and punish maintenance defaulters. The articles states that; "Our officials will execute warrant of arrest on 1,197 targeted defaulters". This article is a clear indication of how shaming as a method to correct and realign fatherhood to the provider role is built into government's conceptions of fatherhood. In this context, it seems like the status of fatherhood and fathering in South Africa is limited in a man's ability to financially support his children and family, the performance of this task is also associated with being a 'good father' [37].

Therefore, the 1,197 fathers who are being targeted by the roadblock hunt mentioned above are 'bad fathers' and are therefore not real men. The reasons for their default are also assumed to be lack of interest since the assumption of the state is that to be a man you need to have employment, this does not take into account the fact that $23.4 \%$ men were out of jobs in the first quarter of 2013 [37]. These statistics show the high unemployment rates amongst men and the unrealistic expectation by the state to label men as heterogeneous in their ability to provide and most importantly in only defining them as providers. Even though the general media tag-line suggests that men are generally not interested in the provider role, on the contrary research indicates that men feel like failures when they are unable to provide for their children $[4,37,39,40]$. For the well-being of men and society in general it is important to see men as more than the provider but as able to contribute to society in more ways. There is, therefore, a need to re-construct the messages that the media and policy makers portray to society about South African fathers.

\section{From Shaming to Affirmation as an Effective Representation of Fathers in the Media}

Even though, affirmation is significant for positive identity formation, it is seldom done in the name of fathers in SA. While, there might be many reasons such as abuse, neglect, father absence that deter multiple discourses of positive fatherhood in the media and other spaces, there are many reasons why it is significant. In line with this idea of positive fatherhood the HSRC study on fatherhood was born of an effort to find stories of positive fatherhood and redefine the role of fathers in South Africa [40]. These stories begin to illustrate that not all fathers are absent, and that other men take care of and contribute to the lives of children who might not necessarily be their own [41]. Again many other men in communities are motivators and mentors in families and to 
young people. Given the scarcity of positives on fatherhood and child support it was a welcomed surprise to find a positive article that re-imagines fatherhood in the face of the singular focus on the provider role.

The article referred to here is titled; "Fathers are more than just ATM's: Society must reimage its notion of the role of the male parent" [28]. This article came out the day before father's day and spoke about men that are unable to pay maintenance for their children but still want to remain active in their children's lives. It read;

\begin{abstract}
"There are various reasons why many men are unable to provide for their children - some of these are forces beyond their control - but this does not mean they cannot love their children, guide and care for them. One respondent emphasised that, "The only thing that we are crying for as men is to see our children, either having money or not having money" [28].
\end{abstract}

This article looks to redefine the false assumption that fatherhood in South Africa is guaranteed through "paying for it" or only through playing the provider role [12]. In a study on unmarried fathers with maintenance experiences it is indicated that these fathers expressed sadness to their inability to be active parents [20]. Research, also indicates that, experiences of the maintenance system $[12,20]$ suggest that fathers only matter when they work and that it felt like it was a crime to be an unemployed father. Therefore, experiences of the maintenance court were negatively experienced by men who were interested in being fathers but were unable to fulfil the provider role.

The media generally reflects a picture of men that do not want to be responsible and involved in the lives of their children. This is done without fully acknowledging that this is not true for all men, there are men who are saddened by not being able to be as effective in their children lives [12, $13,16,20]$. Fatherhood like masculinities [17] should therefore be understood as a complex phenomenon as there are many factors that contribute to its experience.

In the article from the Sowetan titled: SA: A nation of deadbeat dads, tackles the issues of the importance of fathers in their children's lives. The newspaper article shows that children who grow up without their fathers suffer from psycho-social distress which leads to hyper-masculine behaviour for boys and promiscuous behaviour for girls. To indicate this point, the article states that;

\section{"Programmes and campaigns that are aimed at tackling issues that look at popular notions of masculinity and the socialisation of boys and young men, as these factors are perceived to underlie not only the absent father phenomenon, but also the spread of HIV/Aids, violence and the high incidence of rape" [27].}

Even though there is research evidence that indicates that fathers matter, it is important to note that their absence does not necessarily lead to delinquency [25]. In cases of abuse and other negative experiences in father present families, father absence in some context might be a blessing for children [8]. This article does not seek to undermine the struggles that single mothers suffer at the hands of irresponsible men and carelessly planned policies that uphold patriarchal values that oppress women. Its intentions are to motivate for the importance of the father in children's lives. Furthermore, it seeks to stimulate discussion and interventions that work towards bringing the father back into families and their children's lives. This newspaper article is important as it highlights the importance of tackling issues that are central to masculinity and the crisis of masculine development. Additionally, the article illustrates the importance of how men fit into the issues of gender through stressing the fundamental involvement of men in issues of HIV/Aids, gender based violence which includes rape and politics of parenting which looks at the absent father phenomenon. The Sowetan article goes on to suggest that:

"While the government is looking at stricter
enforcement of maintenance payments,
introducing paternity leave, a more equitable
treatment of fathers in legal custody battles, as
well as improving the availability and
accessibility of "family-type" housing in cities,
the real work lies in changing the hearts and
minds of young men right now, according to
organisations grappling with the issue on the
ground" [27].

This newspaper article was refreshing in how it looks at reintegrating fathers in non-normative ways than limit their being to the provider role. The above quote problematizes normative conceptions of fatherhood and how these contribute to family policies which therefore provide limited ideas of fatherhood. As a part of the solution in affirming that men are more than just financial providers, [37, 42] argues that there is a need to advocate for the shared responsibility for parenting and child development amongst both men and women. This can be achieved through encouraging men to be involved in their children's lives regardless of their socio-economic status. Furthermore, more research and scholarly work is needed to document the historical and contemporary determinants of fatherhood and masculinities in South Africa.

\section{CONCLUSION}

Through content analysis of 6 South African newspaper articles on fatherhood and the maintenance system, this article spoke to the role the media plays in influencing conceptions of fatherhood that are in line with hegemonic ideas of masculinity. This was done through a discussion of three important themes, which all tried to show how shaming is used in making fathers into providers. The three sections discussed in findings included a theme on the media's shaming of celebrity fathers and the negative messages of fatherhood, this portrays to the public about men who are unable to support their children. The second theme discussed focused on criminalisation of maintenance defaulting as a form of shaming of men who default. The final theme that the article tackles is that of affirmation of fatherhood as an effective form for making fathers rather than shaming. The themes show that, although the media's role in affirmation is significant very few newspaper articles that speak to positive fatherhood and other ways of being fathers can be found.

In conclusion, we would like to recommend that in addressing cases of maintenance, the media must take a 
responsibility for providing a critical analysis before printing a story. Such an analysis should take into account that issues of maintenance are interwoven with political, social, economic and relational factors which impact how the maintenance system works. It is also important that research and scholarship must continue to grow for the purpose of informing policies and interventions that will advocate for shared responsibility in childcare and development. Finally, the media should look into telling stories of fatherhood with authentic interest to reflect reality of being a man in contemporary South Africa. Again because fathers want to be acknowledged as more than just financial providers their other roles should be captured in reporting on fatherhood.

\section{CONFLICT OF INTEREST}

The authors confirm that this article content has no conflict of interest.

\section{ACKNOWLEDGEMENTS}

Declared none.

\section{REFERENCES}

[1] South African Institution of Race Relations (SAIRR). First steps to healing African family 2009.

[2] Morrell R, Ed. Changing Men in Southern Africa. Pietermaritzburg: Natal University Press 2001.

[3] Ramphele M. The dynamic of gender politics in the hostel of Cape Town: Another legacy of the South Africa migrant labour system. J South Afr Stud 1989; 15(3): 393-414.

[4] Ramphele M. Steering by the stars: Being young in South Africa. Cape Town: Tafelberg publishers 2002.

[5] Brils F. Opportunities and limitations of poor South African fathers. The Child Support Grant and the capabilities of fathers to practice fatherhood in South Africa. Social Policy and Social Interventions. Master Thesis: Centre of Social Development in Africa 2012.

[6] Lesejane D. Fatherhood from an African cultural perspective. In: Richter L, Morrell R, Eds. Baba: Men and fatherhood in South Africa, Pretoria: HSRC 2006; pp. 173-82.

[7] Ramphele M, Richter L. Migracy, family dissolution and fatherhood. In: Richter L, Morrell R, Eds. Baba: Men and Fatherhood in South Africa. Cape Town: HSRC Press 2006; pp. 73- 81.

[8] Morrell R, Ed. Changing men in Southern Africa. Pietermaritzburg: Natal University Press 2001.

[9] O'Connor R. No Man's Land: Unmarried Fatherhood and Caring Critical Social Thinking: Policy and Practice, Ireland: University College Cork 2009; vol. 1.

[10] McComb M, Shaw DL. The agenda setting function of mass media. Public Opin Quart 1972; 36 (2): 176-87.

[11] Schroeder J, Zwick J. Mirrors of masculinity: representation and identity in advertising images. Consumption, Markets and Culture 2009; 7(1): 21-52.

[12] Khunou G. Maintenance and changing masculinities as sources of gender conflict in contemporary Johannesburg. PhD thesis: University of the Witwatersrand 2007.

[13] Khunou G. Money and gender relations in the South African maintenance system. South Afr Rev Sociol 2012; 43(1): 4-22.

[14] Maldonado S. Deadbeat or Dead broke: Redefining Child Support for Poor Fathers 1996. Available at http://www.irp.wisc.edu/publications/ focus/pdfs/foc211.pdf. [Accessed: 04 July 2012].

[15] Armstrong AL. Struggling over scarce resources: women and maintenance in Southern Africa. Regional Report: Phase One, Women and Law in Southern Africa Research Trust. Harare: University of Zimbabwe 1992.

[16] Khunou G. Fathers don't stand a chance: experiences of custody, access and maintenance. In: Richter L, Morrell R,. Eds. Baba: Men and Fatherhood in South Africa. Cape Town: HSRC Press 2006; pp. 26577.

[17] Khunou G. Men's health: An analysis of representations of men's health in the Sowetan newspaper. Communication 2013.

[18] Prinsloo J. Where have all the fathers gone? Media (ted) representations of fatherhood. In: Richter L, Morrell R, Eds. Baba: Men and Fatherhood in South Africa. Cape Town: HSRC Press 2006; pp. 13246.

[19] Barber D. Unmarried Fathers, London: Hutchinson 1975

[20] Chauke P. Fatherhood and the maintenance system: The fatherhood views of unmarried fathers who had been charged or threatened with Maintenance Court ordered child support. Honours Thesis. University of the Witwatersrand 2012.

[21] Republic of South Africa (RSA). Maintenance Act, Act 99 of 1998 Pretoria: Government Printer 1998.

[22] Merriam-Webster dictionary. www.Merriam-webster.com 2013.

[23] McInnes D, Davis, C. Articulating sissy boy queerness within and against discourse of tolerance and pride. United States: State University of New York Press 2008.

[24] Hunter M. Masculinities and multiple-sexual-partners in KwaZuluNatal: The Making and Unmaking of Isoka. Berkeley: University of California 2002.

[25] Langa M. Adolescent boys' talk about absent fathers. J Psychol Afr 2010; 20 (4), 519-26.

[26] Stats SA. Quarterly Labour Force Survey. Quarter 12013.

[27] Grange H. SA: A nation of deadbeat dads. Sowetan $27^{\text {th }}$ March 2013.

[28] Botha M, Thomson, H. Fathers are more than just ATMs. City Press $17^{\text {th }}$ June 2012.

[29] Malatji N. SuperSport United captain a deadbeat dad, court rules. City Press: $19^{\text {th }}$ May. 2013

[30] Mnyakama M. Papgeld dodgers cornered! Offenders could be nabbed even if stopped at roadblock. Daily Sun $11^{\text {th }}$ July 2012.

[31] Mooki O. Teko jail threat over defaulting. Pretoria News $10^{\text {th }}$ May 2012.

[32] De Vos AS, Delport CS, Fouche CB, Strydom H. Research at grass roots: for the social sciences and human services professions. Pretoria: Van Schaik Publishers 2011.

[33] Jupp V. The SAGE dictionary of social research methods. Research methods. Srmo sagepub 2006.

[34] Stokes, J. How to do media and cultural studies. London: Sage 2003.

[35] Woodrum E. Mainstreaming content analysis in social science: Methodological advantages, obstacles and solutions. Soc Sci Res 1984; (13):1-19.

[36] McKee A. A beginner's guide to textual analysis. Metro 127/128, 2001.

[37] Richter L, Chikovore J, Makusha T. The status of fatherhood and fathering in South Africa. Assoc Childhood Educ Int 2010; 86: 6.

[38] Spencer M, Fegley S, Harpalani V, Seaton G. Understanding hypermasculinity in context: a theory- driven analysis of urban adolescent males' coping responses. Res Human Develop 2004; 1(4): 229-57.

[39] Desmond C, Desmond C. HIV/AIDS and the crisis of care for children. In: Richter L, Morrell R. Eds. Baba: Men and Fatherhood in South Africa. Cape Town: HSRC Press 2006; pp. 226-36.

[40] Richter L, Morrell R, Eds. Baba: Men and Fatherhood in South Africa Cape Town: HSRC Press 2006

[41] Mkhize N. African traditions and the social, economic and moral dimensions of fatherhood. In: Richter L, Morrell R. Eds. Baba: Men and fatherhood in South Africa, Pretoria: HSRC Press 2006; pp. 18398.

[42] Datta K. In the eyes of a child, a father is everything: Changing constructions of fatherhood in urban Botswana? Women's Stud Int Forum 2007; 30: 97-113. 